ОСОБЛИВОСТІ ФОРМУВАННЯ ПРОФЕСІЙНОЇ КОМПЕТЕНТНОСТІ МАЙБУТНІХ ФАХІВЦІВ АВТОМОБІЛЬНОГО ТРАНСПОРТУ ЗАСОБАМИ ІНФОРМАЦІЙНИХ ТЕХНОЛОГІЙ

\title{
FEATURES OF FUTURE MOTOR TRANSPORT SPECIALISTS PROFESSIONAL COMPETENCE FORMATION BY MEANS OF INFORMATION TECHNOLOGIES
}

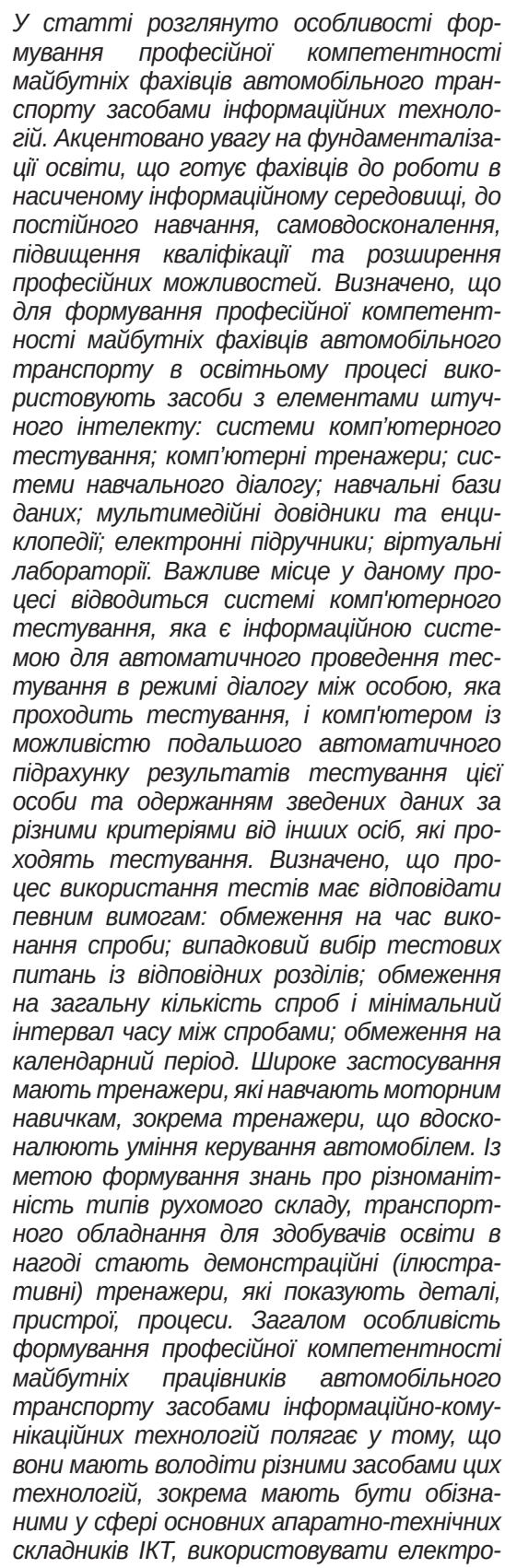

УДК 377.1

DOI https://doi.org/10.32843/2663-

6085/2021/36.32

Дундюк А.ю.,

викладач спецдисциплін

Рівненського автотранспортного

фрахового коледжу

Національного університету водного

господарства та природокористування нні підручники, віртуальні лабораторії, комп'ютерні тренажери.

Ключові слова: професійна компетент ність, фрахівці автомобільного транспорту, тести, комп'ютерний тренажер, інформаційно-комунікаційні технології.

The article considers the peculiarities of the future motor transport specialists professional competence formation by means of information technologies. Emphasis is placed on the fundamentalization of education, which prepares the professionals to work in a rich information environment, for continuous learning, self-improvement, training and professional development. It is determined that for the formation of future motor transport specialists professional competence, the following tools with elements of artificial intelligence are used in the educational process: computer testing systems; computer simulators; educational dialogue systems; training databases; multimedia directories and encyclopedias; electronic textbooks; virtual laboratories. An important place in this process is given to the computer testing system, which is an information system for automatic testing in the mode of dialogue between the person undergoing testing and the computer, with the possibility of further automatic calculation of test results and obtaining summary data on various criteria from other persons undergoing testing. It is determined that the process of using tests must meet certain requirements: restrictions on the time of the attempt; random selection of test questions from the relevant sections; restrictions on the total number of attempts and the minimum time interval between attempts; restrictions on the calendar period. Simulators that teach motor skills, in particular and simulators that improve driving skills, are widely used. In order to form the knowledge about the variety of types of rolling stock, transport equipment for students come in handy demonstration (illustrative) simulators that show details, devices, processes. In general, the peculiarity of the formation of professional competence of future employees of road transport by means of information and communication technologies is that they must have different means of these technologies, in particular must be familiar with the basic hardware and technical components of ICT, use electronic textbooks, virtual laboratories, computer simulators.

Key words: professional competence, road transport specialists, tests, computer simulator, information and communication technologies.
Постановка проблеми в загальному вигляді. Підготовка фрахівців до профресійної діяльності засобами інформаційно-комунікаційних технологій $€$ предметом дослідження багатьох науковців та практиків. Здійснюється акцент саме на фрормування вміння вчитися, оволодівати навичками пошуку інформації, здатності до самонавчання впродовж життя, а не лише нагромадження майбутніми фрахівцями знань, предметних умінь і навичок. Від цього і залежить професіоналізм орахівця [3].

Питання формування профресійної компетентності майбутніх фрахівців автомобільного транспорту є надзвичайно актуальним, адже сучасний ринок праці потребує кваліфікованих конкурентоспроможних фрахівців, здатних до сприйняття та використання на практиці нових наукових ідей, технічних інструментів та методів сучасного 
виробництва. Транспорт - специфрічна галузь господарства. Економіка будь-якої держави не може есрективно фрункціонувати без транспорту. Він не створює, як інші виробничі сектори, нових матеріальних цінностей. Переміщення вантажів і людей, доставка продукції споживачам, зв'язок між виробництвом та споживанням різних галузей господарства $€$ результатом роботи транспорту.

Питання формування професійної компетентності майбутніх фрахівців автомобільного транспорту ще не було предметом ґрунтовних розвідок, тому є актуальним у педагогічній науці.

Аналіз останніх досліджень і публікацій. Проблема компетентності ґрунтовно досліджується в роботах С. Гончаренка, О. Дахіна, Б. Ельконіна, А. Маркова та ін. Психологічні проблеми формування професійних умінь та якостей розглядаються І. Бехом, Г. Баллом, В. Семиченко. У працях В. Аніщенко, Н. Бібік, М. Васильєвої, Н. Демєнтьєва А. Михайличенко, О. Овчарук та ін. вивчаються питання професійної підготовки на основі компетентнісного підходу.

Мета статті - визначити й обґрунтувати особливості професійної компетентності майбутніх працівників автомобільного транспорту засобами інфрормаційно-комунікаційних технологій.

Виклад основного матеріалу. Нині відбувається фрундаменталізація освіти, основними ознаками якої за С. Семеріковим є: а) виділення універсальних, базових знань, які $є$ пріоритетними, що відіграє значну роль у накопиченні інших знань; б) інтеграція освіти, науки і практики; в) перебудова навчального процесу з урахуванням професійної та технологічної мобільності.

А. Ольнева [4] вважає, що фрундаменталізація навчання передбачає обов'язковість вивчення теоретичних відомостей різних наук, оскільки це забезпечує інтеграцію навчальних дисциплін: «Статус фрундаментальності в науці розпочинається 3 етапу розвитку науки «переднього краю», від гіпотези до кінцевої мети. Наука $є$ срундаментальною у розв'язанні прикладних завдань, навіть якщо вони мають різну професійну спрямованість. Наявність спільної предметної галузі, фрундаментального та варіативного складників змісту ... освіти призводить до появи основних нових професійних знань та вмінь майбутнього спеціаліста» [4, с. 10].

Фундаментальна теоретична підготовка не лише озброює майбутнього фрахівця автомобільного транспорту знаннями, що необхідні для повноцінного виконання ним профресійних функцій, а й готує до роботи в насиченому інсоормаційному середовищі, до постійного навчання, самовдосконалення, підвищення кваліфікації та розширення професійних можливостей.

У методичній системі навчання повинні бути одночасно реалізовані принципи фрундаментальності й профресійної спрямованості. Так, освіт- ньо-професійна програма підготовки молодшого спеціаліста галузі знань 0701 «Транспорт і транспортна інфрраструктура» спеціальності 5.07010102 «Організація перевезень і управління на автомобільному транспорті» кваліфікації 3115 «технік-технолог (механіка)» складається 3 трьох циклів дисциплін. На цикл природничо-наукової та загальноекономічної підготовки, що $є$ базовими для цього напряму, нормативно припадає 53\% кількості навчальних годин; на гуманітарну підготовку - 26\%; на професійну підготовку - 21\%, тобто більше половини всього навчального часу відводиться на вивчення дисциплін фрундаментального призначення.

Профресійне навчання у вищій школі для майбутнього фрахівця починається під час вивчення теоретичних питань, фрормування професійних умінь і навичок та засвоєння способів професійнотворчої діяльності. Протягом навчання в рамках ЗВО студенти вивчають теоретичні складники програми підготовки фрахівців (цикл гуманітарних, загальноекономічних, природничих дисциплін).

Під професійною підготовкою розуміємо процес професійного розвитку, оволодіння практичним досвідом майбутньої профресійної діяльності й уважаємо, що компетентний спеціаліст завжди орієнтується на майбутнє, проводить зміни, займається самоосвітою. Особливістю професійних компетентностей $€$ те, що вони реалізуються у сьогоденні, а орієнтовані на майбутнє.

Однією 3 передумов опанування способів вирішення виробничих проблем $є$ системні інтегровані наукові знання. Професійно орієнтовані дисципліни, які сприяють оволодінню студентами теоретичними знаннями щодо сутності і функцій професійної культури, є важливим елементом теоретичного складника підготовки фрахівців. Профресійна майстерність базується на моральноетичних переконаннях, інноваційному характері мислення та системному підході до аналізу складних виробничих ситуацій.

Дослідження проблеми освітньої діяльності, яка реалізується суб'єктом навчання із залученням спеціальних засобів (пристроїв, приладів, апаратів тощо), має давню історію, хоча її актуальність не знижується з часом, а набуває нових рис через те, що в арсеналі педагогіки з'являються нові засоби діяльності, зумовлені стрімким технологічним розвитком суспільства.

Для фрормування професійної компетентності майбутніх фрахівців автомобільного транспорту в освітньому процесі використовують такі засоби 3 елементами штучного інтелекту:

- системи комп'ютерного тестування;

- комп'ютерні тренажери;

- системи навчального діалогу та ін.

Група інших засобів складається з таких видів, як: - навчальні бази даних; 
- мультимедійні довідники та енциклопедії;

- електронні підручники;

- віртуальні лабораторії та ін.

Важливе місце у даному процесі відводиться системи комп'ютерного тестування, яка $€$ інорормаційною системою для автоматичного проведення тестування у режимі діалогу між особою, яка проходить тестування, і комп'ютером із можливістю подальшого автоматичного підрахунку результатів тестування цієї особи та одержанням зведених даних за різними критеріями від інших осіб, які проходять тестування [6].

Найбільше використовуються такі типи систем комп'ютерного тестування:

- за можливістю поповнення бази запитань та внесення окремих змін до програмної оболонки (відкриті, закриті);

- за інтерфейсом взаємодії 3 користувачем (гнучкі, фрормалізовані);

- за середовищем розташування (локальні, глобальні);

- за предметно-галузевою спрямованістю (профрільні, загальні).

Складниками системи комп'ютерного тестування є:

- оболонка тестування;

- статистична база даних;

- система створення та підготовки тестів;

- база даних запитань із доступом до статистичної бази даних;

- база користувачів;

- система керування користувачами.

Розроблення тестових завдань для підсумкового контролю і перевірки залишкових знань проводиться викладачами циклових комісій, які викладають дану дисципліну. Обсяг тестових завдань для підсумкового тестування (кількість запитань або завдань у тесті) визначається залежно від обсягу годин на навчальну дисципліну.

Розроблені тести проходять внутрішню експертизу та затверджуються на засіданні циклової комісії, що офрормляється відповідним протоколом. Для здійснення комп'ютерного тестування викладачі готують набори тестових завдань із дисципліни, попередньо здійснивши їх розподіл на категорії (можливе врахування трьох рівнів складності, розбивки на модулі дисципліни, теоретичний та практичний курси тощо). Тестові завдання надаються на засідання циклової комісії в електронній та друкованій формах за особистим підписом викладача - автора тестових завдань. Далі тестові завдання затверджуються цикловою комісією. А потім викладач особисто генерує тести в систему комп'ютерного тестування, проводить апробацію та за потреби доопрацьовує їх.

Для забезпечення діяльності єдиної системи комп'ютерного тестування перевірки знань і вмінь студентів у коледжі створюється група з тесту- вання, в яку вводять працівників навчального відділу. Головною метою діяльності такої групи $€$ контроль над дотриманням правил використання комп'ютерного тестування знань і вмінь у навчальному процесі коледжу. Циклові комісії відповідальні за наповнення бази тестових завдань із конкретної дисципліни, модуля і т. д. Контроль проводиться один раз на рік, перевіряють їі зміст на актуальність і якість, оновлюючи тестові завдання за необхідністю. Актуальний варіант банку тестових завдань із дисципліни зберігається в матеріалах циклової комісії в електронній (у фрорматі .txt, .doc) і друкованій фрормах.

Процес використання тестів має відповідати певним вимогам:

- обмеження на час виконання спроби, якого було б достатньо для введення відповідей, які студент знає, але недостатньо для пошуку відповідей у сторонніх джерелах інфрормації;

- випадковий вибір тестових питань із відповідних розділів, зміна черговості питань у тесті й черговості відповідей у питаннях, щоб кожний студент у кожній спробі одержував щоразу інший варіант тесту;

- обмеження на загальну кількість спроб і мінімальний інтервал часу між спробами, щоб студент відповідально підходив до кожної спроби й мав мотивацію до вивчення предмету, а не до вгадування правильних відповідей;

- обмеження на календарний період, протягом якого даний тест доступний для складання [6].

Підсумкові тестування 3 навчальної дисципліни проводяться під час модульного контролю та замість (під час або перед) екзамену чи заліку 3 дисципліни на основі затверджених тестових завдань.

Банк тестових завдань для контролю залишкових знань студентів із дисциплін основних освітніх програм створюється 3 метою підвищення якості підготовки фрахівців і ефективності самостійної роботи студентів.

Ефективність системи комп'ютерного тестування можна підвищити за допомогою автоматизованої системи обробки та оцінювання результатів тестування.

Комп'ютерні тренажери (вільного некомерційного використання) срормують практичні уміння і навички застосування набутих знань.

Комп'ютерний тренажер - автоматизований апаратно-програмний функціонально орієнтований комплекс для навчання людини та відпрацювання певних навичок і вмінь [1, с. 32]. У сучасних тренажерах та в програмах підготовки і навчання, на них заснованих, закладаються принципи розвитку практичних навичок з одночасною теоретичною підготовкою.

Сучасний фахівець автомобільного транспорту (технік-технолог) - це, перш за все, компетентний 
у питаннях роботи з документацією, автомобілями фахівець. А компетенція, як правило, фрормується за рахунок набуття професійних навичок на практичних заняттях. Часто в лабораторіях коледжу відсутнє відповідне транспортне обладнання або інфрормаційні системи. щоб навчити студентів практичних навичок, потрібне використання навчальних тренажерів. Інтерактивні тренажери надають можливість повною мірою зануритися у виробничий процес, зімітувати різні ситуації та варіанти роботи з транспортом. Це готове заняття, яке описує конкретне практичне завдання і надає змогу навчитися правильному ії вирішенню. Робота проводиться відповідно до реальних явищ, що точно відповідають навколишній дійсності.

Під час застосування програми-тренажера забезпечуються: послідовне виведення на екран завдань із вибраної теми заданої складності; контроль над діями користувача 3 розв'язання запропонованого завдання; миттєва реакція на неправильні дії; виправлення помилок користувача; демонстрація правильного розв'язання завдання; виведення підсумкового повідомлення про результати роботи користувача (можливо, 3 рекомендаціями чи порадами). Якщо правильно підібрані та використані комп'ютерні тренажери, то це призводить не лише до підвищення рівня знань, а й часто до зацікавлення здобувачів знань відповідними дисциплінами. Під час роботи з програмою-тренажером кожний студент має можливість вдосконалювати навички до бажаного рівня.

Інтерактивний тренажер надає можливість домогтися вирішення низки важливих завдань, які не можуть бути здійснені під час використання інших методів або програм. Кожен тренажер являє собою комплекс операцій, здійснюваних за допомогою програмних засобів.

В освітньому процесі коледжу $€$ в наявності кілька класів-тренажерів. Широке застосування мають тренажери, які навчають моторним навичкам, зокрема тренажери, що вдосконалюють уміння керування автомобілем. 3 метою фрормування знань про різноманітність типів рухомого складу, транспортного обладнання для здобувачів освіти в нагоді стають демонстраційні (ілюстративні) тренажери, які показують деталі, пристрої, процеси. Навантажувально-розвантажувальні механізми, їх призначення, особливості експлуатації складної техніки вивчаються за допомогою тренажерів, які навчають роботі за алгоритмом. Здатність організувати ефрективне використання рухомого складу і його рентабельну експлуатацію, тренувати навички монтажу, збирання систем, а також удосконалювати пошук несправностей та ремонт техніки дають змогу тренажери з навчальними вирішеннями завдань із розгалуженим деревом допустимих рішень. Уміння організовувати роботу відповідно до вимог безпеки життє- діяльності й охорони праці, фрормувати навички поведінки в нештатних або аварійних ситуаціях, у складних ситуаціях в управлінні транспортними засобами здійснюється за допомогою тренажерів, які навчають розпізнаванню образів.

Використання в освітньому процесі навчальних комп'ютерних інтерактивних тренажерів призводить до значного зменшення помилок та недоречностей, збільшення швидкості прийняття рішень, скорочення часу навчання, адекватної оцінки рівня отриманих знань та набутих навичок, індивідуалізації навчання.

У своїй роботі студенти використовують системи $з$ енергозберігаючими рефлективними екранами на основі технології «електронного паперу» («електронних чорнил»- E-Ink) [5, с. 53-54]. Пристрої, в яких використовуються папероподібні екрани, позиціонуються переважно як електронні книжки (пристрої для читання - E-Book). Електронний підручник - це інфрормаційна система (програмна реалізація) комплексного призначення, яка забезпечує за допомогою єдиної комп'ютерної програми, без звернення до паперових носіїв інфрормації, реалізацію дидактичних можливостей засобів IKT у всіх ланках дидактичного циклу процесу навчання:

- постановку пізнавального завдання;

- пред'явлення змісту навчального матеріалу;

- організацію застосування первинно отриманих знань (організацію діяльності 3 виконання окремих завдань, у результаті чого відбувається орормування наукових знань);

- зворотний зв'язок, контроль діяльності студентів;

- організацію підготовки до подальшої навчальної діяльності (завдання орієнтирів для самоосвіти, для читання додаткової літератури) [2].

У коледжі створено електронну бібліотеку, а також електронну базу навчально-методичної літератури, існує можливість працювати з електронними підручниками будь-де за наявності Інтернет-з'єднання. Також є змога закачати електронні підручники на будь-який носій (флеш-диск, телеорон, планшет, ноутбук та ін.) у разі відсутності Інтернету. Для здобувачів освіти доступна велика кількість різноманітних підручників, навчальнометодичної літератури за вибраною предметногалузевою спрямованістю. Перевагами електронних підручників є їх безкоштовність за винятком невеликої кількості специфічних видань, а також можливість особистих налаштувань під час навчання по електронному підручнику, наприклад розміру та типу шрифту; не зношуваність на відміну від паперового.

Електронна книга як ТЗН надає значні переваги як студенту, так і викладачу, робота якого частиною пов'язана з різними текстами (конспекти лекцій, завдання контрольних робіт, довідкова 
література тощо). Електронні книги бувають енциклопедичні, інформаційні, навчальні й контролюючі. Значна їх частина - методичний комплекс із предмету - практично весь час використовується в роботі. Невід'ємною частиною електронних підручників $є$ практичні і лабораторні роботи.

Висновки. Таким чином, особливість фрормування профресійної компетентності майбутніх працівників автомобільного транспорту засобами інформаційно-комунікаційних технологій полягає у тому, що вони мають володіти різними засобами цих технологій, зокрема мають бути обізнаними у сорері основних апаратно-технічних складників IKT, використовувати електронні підручники, віртуальні лабораторії, комп'ютерні тренажери.

\section{БІБЛІОГРАФІЧНИЙ СПИСОК:}

1. Андрощук О.С. Розробка комп'ютерних тренажерів щодо навчання персоналу Держав- ної прикордонної служби України Вісник Національної академії Державної прикордонної служби України. 2014. № 1. С. 12-26.

2. Гуревич Р.С., Кадемія М.Ю., Шевченко Л.С. Інформаційні технології навчання: інноваційний підхід : навчальний посібник / за ред. Р.С. Гуревича. Вінниця : Планер, 2012. 348 с

3. Компетентнісний підхід у сучасній освіті: світовий досвід та українські перспективи Бібліотека 3 освітньої політики Київ : К.І.С., 2004. 112 с.

4. Ольнева А.Б. Вариативный подход к математическому образованию в техническом вузе : автореф. дис. ... докт. пед. наук : спец. 13.00.08 «Теория и методика профессионального образования» ; Астраханский гос. тех. ун-т Ярославль, 2006. 19 с.

5. Теплицький І.О. Новий технічний засіб навчання - електронна книга. Рідна школа. 2007. № 7-8. C. 53-54.

6. Фетісов В.С. Комп'ютерні технології в тестуванні : навчально-методичний посібник. Ніжин : ПП Лисенко М.М., 2011. 140 с. 